\title{
Experienced Teachers Reflecting on Challenging Situations in School
}

\author{
May Britt Postholm \\ Programme for Teacher Education, Norwegian University of Science and Technology, NTNU, Trondheim, \\ Norway \\ Email: may.britt.postholm@ntnu.no
}

Received 18 May 2016; accepted 20 June 2016; published 23 June 2016

Copyright (C) 2016 by author and Scientific Research Publishing Inc.

This work is licensed under the Creative Commons Attribution International License (CC BY).

http://creativecommons.org/licenses/by/4.0/

(c) (i) Open Access

\section{Abstract}

The aim of this study is to develop an understanding of how teachers in a lower secondary school deal with challenging situations in the classroom and whether or not they experience that they can obtain help in coping with these situations. Three teachers with five to nine years of teaching experience took part in semi-structured interviews. Before the interviews and before they started to write log book entries for fourteen days to document and reflect on these situations as they occurred in their work in school, the teachers were told that they were to focus on what they felt were challenging situations in their practice. The study shows that these three teachers have various experiences of what they find is difficult to tackle, and that these situations are related to experiences they have had before they started in their profession, and to their values and beliefs. The study also shows that there are common situations that the three teachers perceive as difficult. It becomes evident from the analysis of the data material that they think that good relations between teacher and pupils and between pupils themselves, thus a trustful learning environment, are a good foundation from which to learn to deal with challenging situations in the classroom. They also agree that sharing experiences and solving problems together helps them to tackle challenging situations in school. The teachers think that their basic teacher education has had little influence on their school practice, and they emphasise that further education taken either on campus or with school as the learning arena helps them in their daily practice when confronted with challenging situations.

\section{Keywords}

Experienced Teachers, Challenging Situation, Reflection in Practice, Continuous Professional Development, Learning in School, Qualitative Method

\section{Introduction}

Classrooms, according to Doyle (2006), are complex systems of individuals and groups, curriculums, aspirations 
and perceptions of connections. He also states that the teacher's actions and the pupils' involvement are part of an activity in a classroom in a given period of time, and that the classroom is a system of related activities powering what occurs in this classroom. Both teachers and pupils bring experiences with them from outside the school context and into the classroom. Usually the teacher is the one to initiate the activities that are played out in the classroom, but, according to Doyle, it is important that teachers and pupils work together to create a context which forms the basis for interaction in a dynamic way. Doyle points out that the pupils also must feel that they are respected if a productive context is to be maintained. This means that the teacher becomes the key actor in the creation of productive activities and good relations in the classroom.

Several researchers have pointed out that emphasis should be placed on the teacher as a person in connection with teaching and the practice in school (Day, 1999; Palmer, 2003). Day (1999) refers to the "personalized nature of teaching” (p. 94), which points out that not just cognition but also emotions play an important role in teaching (Hargreaves, 1998). In the word emotion, motion is the key element, and, needless to say, means movement. Emotions, together with cognition, give the possibility of achieving double developmental power. If the teacher is to feel happy and perceive the school and the work together with pupils and colleagues as meaningful and motivating, it is necessary that he is in practice as a whole person. Thus there is both an individual and social responsibility resting on the teacher.

The aim for the school is that pupils will develop their general cultural belonging and education, and their knowledge. If pupils are to learn in school, teachers must have both content knowledge and knowledge on how to teach their subjects: they need pedagogical content knowledge (Shulman, 1986). Furthermore, teachers have to know their pupils. As mentioned above, no pupil enters school without prior experiences. Pupils come from a local context that influences who they are, their interests and meanings. It is therefore necessary for the teacher to know his pupils' backgrounds and about what experiences outside school influence them and their motivation and willingness to learn. This is also fundamentally important if teachers are to genuinely see their pupils. Teachers do not just teach academic material, they teach children and young people.

Teachers plan their teaching and undertake it together with the pupils. But the lessons may not always turn out as planned as unexpected episodes can be part of the processes that take place together with the pupils. In the midst of their teaching, teachers have to make decisions that are not pre-planned. Teachers may have experienced some of the situations that arise before, and can thus act in a more standardised way than when entirely new situations become part of classroom life. Teachers spend most of their time together with their pupils, but they also have colleagues and parents to deal with in their professional work. Collaboration with parents (Dunst, Rounds, Trivette, \& Hamby, 1992) and with colleagues (Avalos, 2011; Desimone, 2009; Postholm, 2012) can support the teachers' teaching of the pupils in the classroom, but challenging situations can also arise in these collaborative circumstances. The purpose of the study that this article is based on was to detect what challenging situations experienced teachers encounter in their school practice and how they cope with and reflect on these situations. The problem formulation for the study was: How do experienced teachers respond to and reflect on challenging situations in school?

In the following text I will present the theoretical framework for the study before I explain the method used to study the teachers. The methodology section is followed by a presentation of each teacher, their experiences of challenging situations and their reflections on them. This is followed by an analysis of and discussion on the findings before the article ends with concluding reflections.

\section{Theoretical Frame of Reference}

The theoretical frame of reference presents relevant theories that will be used to analyse and discuss the findings of the study. The presentation will be focused on the following key concepts: the art of the teacher, substantive and contextual theories, teacher collaboration, behavioural problems, relations, mindfulness and meaning-oriented reflection.

A teacher's practical experience gained together with pupils can be called the art of the teacher (Durkheim, 1956). This practical experience is developed through practical training, learning of skills, personal experience and education. Thus theories on teaching and learning are part of the teacher's practical experience. The art of teaching cannot, according to Durkheim (1956), be separated from reflection because the teacher's method competence and the organising of the teaching will become habits and routines if he or she does not reflect on the methods, goals and means. When teachers reflect on their teaching, routines are then open to change. If 
teachers do not have the ability and strength to reflect on their teaching, it can be mechanical and repressive, according to Durkheim. If teachers do not reflect on their role as leaders for the pupils, they may also find it difficult to develop good relations with them.

Dewey (1916) claims that an educative experience means changes in the people who are experiencing something. The change brought about by an action is reflected back to the acting people who then can learn. According to Dewey, we are able to have ideas about a thing, which means foreseeing the probable consequences of how it acts upon us and vice versa. He states that language is the most significant means for creating reflection, and this reflection can be conducted both individually and collectively, as when teachers reflect together.

But when asking what teachers actually bring with them to school and the classroom that can help them to reflect when challenging situations become a reality, the answer is that they bring their subjective, individual theoryto their school practice (Postholm, 2010). This theory comprises experiences, perceptions and theories they have read about and internalised and made their own. Experiences they have had as a pupil can also be part of this individual theory. The teacher or teachers that taught you as a pupil can be a model for your own teaching practice. Lortie (1975) calls this "apprenticeship of observation”. Teachers will also have experiences of practice in school, which, building on Lortie's construct, can be called "the apprenticeship of practice" (Postholm \& Rokkones, 2015). Subjective individual theory is an action theory that usually cannot be put into words, but it can be observed. It is a theory in use (Argyris \& Schön, 1978). This theory in use could be developed jointly with further experiences and academic theories, but experiences and theories have to be brought together in reflections (Postholm \& Rokkones, 2013). When a teacher acts in the here and now, in the middle of a situation, contextual knowledge, not general theory, is applied. When it comes to here-and-now situations, teachers benefit from having examples supplied by colleagues showing them how unforeseen situations or incidents can be dealt with (Postholm, 2012). When reading texts focusing on qualitative classroom research, teachers can also experience the described practices as parallel experiences and adapt them to their own situations. Such studies represent contextual knowledge that can be used as thinking tools (Gudmundsdottir, 2001) by teachers to help them deal with challenging situations in their classroom.

Theory can also be a tool for teachers when they sit together to plan and reflect on their teaching. Then both general theories about teaching and learning and theories connected to specific situations in the classroom and school can help them both to plan and reflect on the activity in school. Research shows that teacher reflection based on practice actions actually leads to changes in practice (Camburn, 2010). Camburn's study also shows that the opportunity to reflect together with colleagues leads to more reflection, and that such reflection may be a powerful contribution to teachers' learning. Several studies show that providing teachers with opportunities to interact in a community of professionals is a key element in a professional learning context (Fishman \& Davis, 2006; Grossman, Wineburg, \& Woolwort, 2001; Meirink, Meijer, \& Verloop, 2009).

Marzano (2009) maintains that good relations with pupils are the cornerstone in classroom management. Teachers with social and emotional competence and who experience well-being are well positioned to contribute to supportive teacher-pupil relations. They can be good classroom managers and role models for the pupils when it comes to desired social and emotional behaviour, and can contribute to a good class environment, which in turn contributes to the social, emotional and academic outcome of the pupils (Jennings \& Greenberg, 2009). When it comes to the concept of mindfulness, which is also introduced in discussions on classroom management, researchers believe that this can be learnt, and find that being mindfully present is associated with good classroom management (Marzano, Marzano, \& Pickering, 2003; MacDonald \& Shirley, 2009). Behavioural problems in the classroom constitute one of the major reasons why teachers fail to feel comfortable in their work (Lewis, Romi, Katz, \& Qui, 2008), and behavioural problems are what often lead to unexpected and sudden situations in the classroom that the teacher has to deal with.

Mindfulness has been defined as a state in which one is highly aware and focused on the reality of the present moment. One accepts and acknowledges this moment, without getting caught up in thoughts about the situation or emotional reactions to the situation. When you act mindfully in a stressful situation, you respond to the situation instead of automatically reacting to it. You are paying open-minded attention and you are present on purpose (Kabat-Zinn, 1984, 1990). This is a purposeful and non-judgemental awareness of present-moment experience (Kabat-Zinn, 2003). According to Kabat-Zinn (Paulson, Davidson, Jha, \& Kabat-Zinn, 2013), it is easy to misunderstand what non-judgemental means, and that it does not mean refraining from making judgements, but rather suspending judgement.

To succeed in a job and satisfy one's own needs and intentions as to what is important, it is necessary to be 
aware of what these needs and intentions are. Hamachek (1999) claims that the more you know about yourself, the more your personal decisions will contribute to better teaching (p. 209). The onion model developed by Korthagen (2004) illustrates that teachers must start with themselves. The model comprises layers, from the outer layer of Environment, through Behaviour, Competencies, Beliefs, Identity, and at the centre, Mission. Hoekstra and Korthagen (2011) instantiated the model by asking questions: Environment: What am I dealing with? Behaviour: What do I do? Competence: What am I competent at doing? Beliefs: What do I believe? And Mission: What greater entity do I feel connected with? This model indicates that teachers must think of what is important for them and what they really believe in, and thus what their beliefs and values are. The essence of this model represents teachers' core qualities and core values, and it becomes a meaning-oriented reflection (Hoekstra \& Korthagen, 2011). In this type of reflection process, people can be aware of what they believe in. The onion model visualises the layers that can be part of a meaning-oriented reflection. Such a reflection is also about a relation between the person and his or her professional work. This means that teachers have to be both cultured and educated persons, and enter the teaching holistically, as whole persons.

\section{Methodology}

\subsection{Sample and Data Collection}

Qualitative research interviews were used as the data collection strategy to find answers to the problem formulation and thus gain insight into teachers' thoughts, knowledge and attitudes connected to situations in their practice in school (Kvale \& Brinkman, 2009). I interviewed three teachers who were teaching at the same school, working at the Year 8level and belonging to the same teacher team. They have altogether 61 pupils divided into two classes, and each class is split into two groups with each their headteacher. This means that there are four teachers serving as headteachers in this class, but as one of them is a newly qualified teacher, she did not satisfy the experienced-teacher criterion for my sample. The participating teachers had from five to nine years of experience and could therefore be regarded as experienced teachers (Richter, Kunter, Klusmann, Lüdtke, \& Baumert, 2011). I have named the teachers Jane, Kari and Peter for this paper. They were told that they were to focus on situations that they perceived as challenging in their practice, and they were asked to reflect on these situations.

The interviews were conducted at the end of the first semester of the school year, which means the teachers had taught the pupils for half a year. They were first interviewed individually. After the first analysis of the three individual interviews I conducted a focus-group interview with the teachers which functioned as a member-check (Lincoln \& Guba, 1985) of the initial analysis, and as a continuing collective reflection on challenging situations in practice. This also created data material for the study. Prior to the individual interview with each of the teachers I asked them to write log book entries on the following points for a period of fourteen days:

Describe the situations

How did you experience these situations?

What did you think?

How did you proceed—what helped you?

How did you perceive the continuation?

The intention of the log book entries was to make the teachers aware of various situations in practice and how they responded to them, and to prepare them for the interviews. During the interview the teachers were asked to talk about the situations they had written about in their log books. They were also asked the following questions:

What knowledge and beliefs did you use when you responded to the situations?

Where does this knowledge come from?

How do you experience the teacher team's role when you deal with such situations in practice?

Have you recognised any changes in how you respond to such situations during your career as a teacher?

These were the questions that framed the interviews from the outset, but my follow-up questions on what the 
teachers said and also the teachers' descriptions and utterances broke away from the question frame in the interview guide. Thus I can say that I was using semi-structured interviews (Fontana \& Frey, 1998).

\subsection{Data Analysis}

I transcribed the interviews and proceeded with the analysis of the data material by using the constant comparative analysis method (Strauss \& Corbin, 1998) to find patterns and condense the material to make it reportfriendly (Garfinkel, 1967; Sacks, 1992). The material was coded by putting labels on the situations the teachers described. I used this coding process to develop two main categories, "seeing the pupils" and "teachers' learning", which are more abstract terms than the labelled codes. The selective coding process, focusing on what this is all about, resulted in the core category "teachers' continuous professional development". The labels structure the presentation of each teacher, and the developed categories comprise the foundation for the following analysis and discussion of the findings. Below I present the codes labelling challenging situations, the codes related to sources of help and the common codes from the focus-group interview separately, and also the main categories and the core category in Table 1 . These codes and categories are connected to each teacher.

\subsection{Quality and Ethics}

To ensure the quality of the work, as mentioned above, I haveused member-checking (Lincoln \& Guba, 1985) of the first analysis of each interview. The teachers stated that they felt the descriptions of the situations, their responses and their knowledge, beliefs and attitudes were accurately reported. The participation in the research study was based on informed consent, and the article complies with the ethical principle of making participants anonymous (NESH, 2006). Consequently all the teachers have been given fictitious names.

The descriptions and experiences that have been presented are connected to the specific teachers in a teacher team at one school. All the same, the findings presented may have importance beyond their context if readers of thearticle can use it to think creatively and imaginatively (Geertz, 1973), thus using it as a thinking tool (Gudmundsdottir, 2001). This means that the findings can contribute to an understanding of how experienced teachers reflect on and deal with challenging situations in their practice. The way the teachers think and have knowledge about the incidents described, and their attitudes to them, can be interesting for other in-service teachers and for pre-service teachers in teacher education when they develop their reflection in practice or prepare for various situations in practice.

\section{Findings}

In the following I will first present the teachers and their descriptions of their experiences of challenging situations

Table 1. Overview of the codes and categories developed in the study.

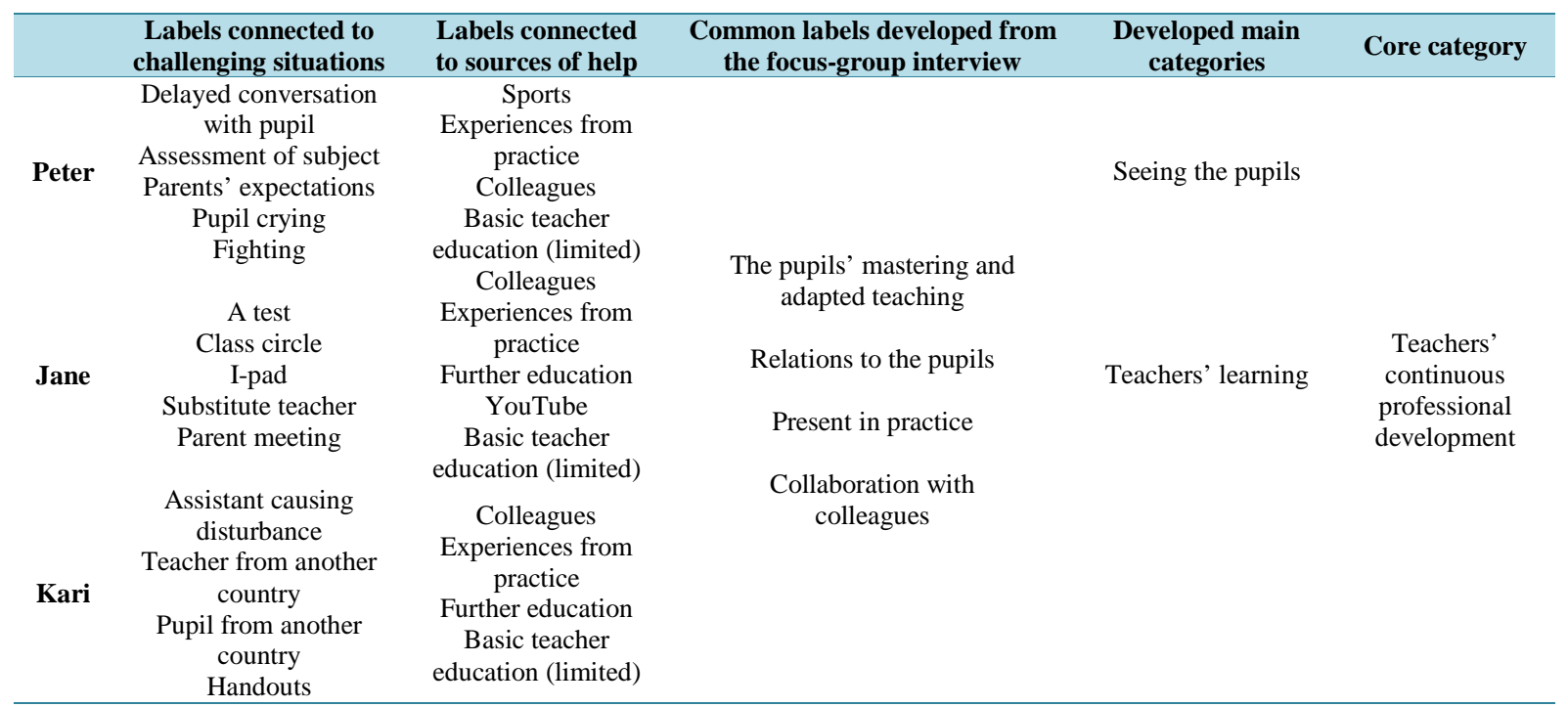


in school, and then their reflections on these situations. After the individual presentations, I will present the reflections from the focus-group interview that functioned as a meta-reflection on the already reported situations.

\subsection{Peter's Descriptions and Reflections}

Peter has nine years of experience as a teacher after completing his teacher training. He has also worked at a school and a kindergarten before he took his teacher training. Now he is the form teacher for one of the groups in one of the Year 8 classes at the school. This is the first year he has taught these pupils. Peter is the only participant who starts to discuss the concept of challenging situations: "When are they a problem and when are they a challenge?" He continues: "When the challenges become difficult to deal with or solve, then they become a problem, but I think I would rather describe some challenges, not problems".

He explains that he finds some challenges are due to the system at the school. The first scenario tells about him having to delay a conversation with a pupil because he has to step in as a substitute teacher. The second tells about pupils taking the subject "working life/job placement" and about assessing these pupils. Peter has the responsibility for the pupils who have chosen this subject. He talks about there being no time to observe the process over a period of time, so it is the representative at the work place who gives the feedback that is the basis for the assessment of the pupil in this subject. Peter finds the feedback from the employer to be inadequate, and wonders what would happen if a pupil chose to complain about a mark: "This could be a problem for me," he says.

He goes on to say that he also experiences that he does not live up to the expectations of the pupils' parents. He talks especially about one pupil and the inadequacy he feels every day about satisfying this pupil's needs. He thinks that he does not have a good rapport with the pupil yet because another teacher the pupil is acquainted with from earlier school years still helps him during his school day. "But I'm the one who has to have the overview of the pupils' learning and development and tell the parents if they phone the school,” he says. He finds that he has good relations with his pupils, and that the pupils feel confident with him as their teacher. He thinks that he has a positive view of people and thus also the pupils, and that he is in general a positive person. There is no bad behaviour in the class, according to the teacher, and there have been no conflicts in the class.

When it comes to challenges in the classroom that suddenly arise, he has two episodes he wants to mention. "One day a girl started to cry all of a sudden, and she left the classroom," he says, and continues:

And then I had to leave the other pupils in the class on their own. Something had happened in her family, something with one of her siblings, and then suddenly it became emotionally challenging for her during the lesson. It was not a big challenge for me, because I don't have any problems leaving the class on their own for a few minutes, some things are more important than others, so I have not regarded it as a problem. But it is a challenge there and them that you have to cope with something that is not part of normal occurrences.

Peter says that he feels safe in his role as a teacher, and he believes that other teachers probably would have remained in the class. But he can tell the pupils what to do before he leaves, and then all goes well: "I think it's because I have good relations with my pupils and thus a relationship of trust, the pupils experience me as a confident person," he reasons. Peter is aware of the importance of talking to the pupils during transition periods in the teaching process, and he tries to involve all the pupils. He explains that the pupils themselves have developed the rules for classroom behaviour, and he emphasises that a good class culture allows the pupils to make mistakes, seeing them as part of a good learning process. Another episode Peter talks about is from a lesson in physical education. Two boys started to fight. "You don't know the background for this sudden fight, but you have to act," he says. He explains that he has learned during a long life that you do not start by questioning there and then about the cause of the fight. "You have to calm the situation down and talk afterwards. Your way to deal with this is so deep-seated because you have experienced such episodes many times before,” Peter explains. Peter does not make any abrupt decisions when it comes to sudden incidents, but registers what happens and thinks about it. "Sometimes you have to act intuitively, but you reflect afterwards," he explains.

Peter thinks that in sports he has learned free of charge what being a teacher is all about because he has served in various roles as a trainer. "That's where I've learned most of my pedagogical insights; it's practical pedagogy. Theory, that's just some anchor points to link your understanding to,” he says. He does not see theory as something that can help his teaching practice, but he confers with his colleagues in his team if he needs to discuss challenges, for the most part about adapting teaching for pupils. All the same, he thinks it is also less formalised to reflect together with colleagues: "the teachers in my team and I have our desks in the same room, and if I 
have something I'm wondering about, the threshold for asking is low. He thinks that he learns a lot from these collaboration processes and thus develops as a teacher.

\subsection{Jane's Descriptions and Reflections}

Jane has five years of experience as a teacher. She has a varied background as she has worked as a bank director and a school leader before starting to teach pupils. She is very satisfied with the pupils in her class, and the pupils also feel happy with her. Jane also has situations she can mention that suddenly became a challenge during her teaching and also other situations that challenge her in her daily work. The first one is an episode when the pupils are given back a mathematics test. She says:

When they got the test back, they were supposed to work in groups of four and discuss it. This was exciting right up until they saw their marks. Then they were finished. But that was when we were supposed to really start working with the test, but it just didn't work. And it has been good for me to write this log which you asked me to do, because then I could reflect on how to do things differently. Definitely, they should not be given the mark immediately. We have some forms pupils use to evaluate their own performance in various areas in connection with a test, so actually I could have given them this form, and they definitely should not have been given the mark. The excitement was gone then. If they get the mark too early then there are some who are unhappy, and they undermine the process, they don't want to do anything, and then I in a way give up. But I did not want to break up the groups there and then.

She thinks that the next time she will put fours desks together, this time she had four pupils sitting around two desks and that was too tight. She will also make handouts with exercises. When they summed up the lesson, the pupils also stated that they thought the situation was a bit noisy and they admitted that they did not work on the tests. Jane told them that they had been given the chance to sit together in groups and to choose groups themselves. But, she told them, they were not mature enough for this yet so that the next time they would have to work individually. "The challenge with this collective punishment is that some of them work in a satisfying way," she says.

In the second episode, she has arranged for a class council with the pupils sitting in a circle. All the utterances from the pupils are negative, and she does not manage to stop the chain of negative talk about the school canteen. Looking back, she feels that she failed in this situation, and she is not happy about this because she thought the pupils were lucky to have the canteen. She did not know how to intervene. Luckily a girl in the class broke the chain of negative utterances, she says. "She turns everything around; if she had not been in my class, the class circle would have ended in a negative way.” Jane says that she should have planned some themes to use for the discussion which would have enabled her to turn the situation into a constructive conversation. She thinks that this is similar to when the class becomes increasingly more unruly. "What should we do then?" she asks.

Jane then refers to another situation she thinks it is not too easy to be prepared for and tackle proactively. She mentions a situation in class when the pupils had borrowed I-pads from a teacher education institution and knew that they were just supposed to use them to solve the tasks they had been assigned. When she discovers that one of the pupils has taken a picture that was not part of the task, she reacts immediately. As she thought that this was a bad thing to do, she went straight up to the pupil and said: "Why did you do this?" She says that this was her spontaneous reaction, and that the pupil was very flustered. It turned out that he had not taken the picture. "I see now that I reacted without thinking, you react at once without a chance to reflect on it," she explains. She says that she had to apologise, and that she is a person who wants to immediately put things right. As a consequence, she might react before she has the full overview of the situation, she explains.

Jane has also written in her log book about a parent conference where the pupil was to take part. The parents are divorced, and Jane sent an invitation to them both as is standard procedure. This pupil lives with her father, and after talking to him on the phone, Jane realised that the pupil and her father would not come if her mother attended the conference. Jane had already received confirmation from the mother that she was coming, and she wrote back to her saying that she had to clear this with her daughter. But she had obviously not done that before the conference. When it started the mother was sitting alone in the conference room while the father, standing in the hall, refused to come into the room. Jane also had to tell this to the pupil as she had promised to do beforehand if the situation should turn out as it did. She started the meeting by telling the mother that her daughter would not attend if she was there. "But what was the point, the parent-teacher conference is an assessment for learning, and it is meaningless if the pupil and the father who she is living with don't take part,” Jane states. She 
told the pupil that this was the last time this would happen, and she received the school leaders' support on this point. "My responsibility is that the pupils feel safe at school, this pupil did not feel safe," she adds. Jane says that she should have checked this out beforehand, and felt that she had put the girl in a difficult situation.

Similar to Peter, she thinks that being a substitute teacher is a challenge when nothing has been planned for the lesson or lessons beforehand, as can be the case when someone is suddenly sick. "You're asked to take this lesson right before it begins," she says. She tells about one morning when she was told that she would have to step in for another teacher and she did not know what to do. As the subject for the lesson was Norwegian, not one of her subjects, she ran to ask teachers familiar with the class in question to ask them what to do, ten minutes before the lesson was to start. She had planned to work on her own things this morning, but had to set them aside. From experience, she plans her lessons the night before, so she is not confident with such a situation, but realises that someone has to work with the pupils. "This is part of our everyday life in school," she says.

Jane thinks that both her education and her experience help her during her practice in school, but she suggests that it is good to reflect together with her colleagues, and she especially asks Peter for advice. "We do not have much time to reflect together, but Peter always finds time. You tend to ask people whom you know will take the time to discuss things together with you," she says. Jane talks to him about how to teach the pupils to understand subject material and also about pupil behaviour in school, and how they approach and tackle various situations. Jane says that they do not have subject teams, but still, the math teachers voluntarily meet at eight o'clock in the morning once a week to exercise and plan teaching together. She adds: "We won't develop if we don't share experiences". She also shares experiences from her practice with a teacher working at another school. She does not read theory by herself, but she has taken further education in guidance counselling, and she thinks that this helps her in dialogues with her pupils. If other teachers are not available, she has used YouTube sometimes to get ideas for her teaching practice.

\subsection{Kari's Descriptions and Reflections}

Kari has worked as a teacher for seven years. She has worked at various schools, mostly small schools, and has been responsible for the reception class ${ }^{1}$ for three years. Now she is the main teacher for a group of pupils in Year 8. She also has an immigrant background, coming to Norway from a country in Eastern Europe when she was eight years old. She mentions some episodes, and also talks about some ongoing challenges that disturb her during her practice in school.

Kari starts by mentioning a pupil who has an assistant to help him during the school day due to his special education needs. When the pupils have presentations in class, the assistant sits beside him and talks: "It's not the pupils I have to keep quiet, it's him. I don't like it, he disturbs a bit,” Kari says. She states that her colleague has advised her to talk to him, but she has not done so yet. She is afraid that if she does, she might widen the distance between the teachers and the assistants at the school. Kari feels that the assistants look at the teachers as being larger up the hierarchy ladder at the school, and she is afraid that talking to the assistant about the challenges she experiences might increase this distance between them.

Kari thinks it is challenging that first-language teachers from other countries have other expectations than the teachers from Norway. She mentions that these teachers give the pupils bad marks because of what they perceive as a poor effort. Kari says that she talks about this to these teachers and asks if they are sure that the poor effort is perhaps due to their low motivation to work. Kari then says that she is not sure that they have understood their duties. "But they require more effort and are stricter than we are," Kari adds.

Kari has a pupil from Poland in her class, and she finds it challenging that he requires individual help all the time. Before he can start to do anything, Kari has to come to his desk. Kari states that he is so used to this that he does not listen to her collective explanations for a task. "But," she says, "he understands the Norwegian language quite well."Moreover, almost every day this pupil phones her in the afternoon after school to ask her about homework. "He needs her to instruct him directly," Kari explains. She adds that she has many pupils with special needs and also some bright pupils who need extra challenges and also positive feedback on their ability to manage the tasks. During her further education she has written about the importance of seeing the pupils, but she really experiences it as a challenge during a lesson to see all of them. She says:

You have 30 pupils and you are supposed to pay attention to all of them, but I really find it challenging. Someone wants my help all the time, I feel that pupils are calling my name constantly, and I have to move

${ }^{1}$ Class for newly arrived non-native pupils and adults, preparing them for the regular school. 
from one pupil to another, and then the school bell rings, the lesson is over.

Kari also mentions that she has watched football matches in the evenings with non-native pupils and that she also goes with them to buy sportswear so that they do not stand out from the others.

Kari mentions a situation in class that disturbs the ongoing learning processes. She says that a very tricky situation can arise if they use handouts instead of a book. Handouts that she gives to the pupils the day before can disappear, and then she has to go to the second floor to copy more. Moreover, she has to leave the pupils alone in the classroom. She continues:

It becomes a little bit tricky when you're standing ready in the classroom and some of them don't have their handouts. Then I'm running almost every time to the copy machine. So I have been a little bit strict with the pupils saying that they need to bring both their books and the handouts with them. It is a little bit uncomfortable standing there without the handouts and a lesson spoiled.

Kari thinks that she learns from various sources. She can learn from her own mistakes. She states that in the beginning it was very difficult to calculate how much time you had to use, and sometimes she could be finished with her planned activities after 15 minutes. Back then she did not bring extra exercises with her like she always does now. She also thinks that the further education she has taken has been a great help to her. These studies helped her directly in her work at school, especially as she was teaching in school along with her studies. When she started in teacher training it was like a new world for her. She says: "I really think I could have learned more from the basic teacher education if I had taken it now instead, because back then I had no experiences to connect the theory to," she says. All the same, she thinks that she has learned the most from the experience she has gained in school and from collaboration with colleagues.

\subsection{The Teachers' Joint Reflections}

When I interviewed the teachers together I first described what I had found during the individual interviews. Next we commenced a dialogue based on the question of what the teachers experience as a challenge in their practice. The conversation between the teachers and I was about the pupils' feeling of mastering their situation and the teachers' feelings as to whether or not the pupils mastered the activities and tasks they were assigned. Peter feels that he needs more time together with the pupils who do not feel they are mastering things. "But then we have to move on to something new, the timetable says so," Petersays. Jane asks other teachers for help and tries to teach the subject material in new ways to help the students understand. When the pupils do not master their school work, Jane becomes a little bit frightened. "What if they don't understand the next time, I fear that I'm not teaching them well enough," she worries. It is important for the teachers that the pupils master their tasks and understand the content they are working on. The teachers are immediately happy when they observe that their pupils are succeeding. Jane explains: "All of us like positive feedback. We can see that they succeed, we observe their happiness, they do not need to say anything, we see it and that is enough". They all agree that the pupils need teachers who are present in their practice and see them. The teachers think that their collaboration is the key to doing a good job together with the pupils, for both their personal and academic development. The teachers admit that they do not use theory, neither during the planning nor during the reflection on practice, but their subjective individual theories (Postholm, 2010) and their action theories (Argyris \& Schön, 1978) permeate their practice.

\section{Analysis and Discussion}

The teachers present various episodes and situations and how they deal with and reflect on them. It is obvious that the three teachers have their pupils in focus during their practice. Peter shows respect for his pupils when he thinks being forced to delay a conversation with a pupil is a challenge. He also believes that it shows a lack of respect when pupils are given marks on insufficient grounds. Peter feels he has good relations with his pupils and that they are confident with him. He has a positive view of people and he is able to determine what is most important for him. He thinks it is important to satisfy the parents' expectations, for example when they phone the school to obtain information about their child, but thinks it is also necessary to have close relations with the pupils. He obviously has values that help him to sort out what is important, as when the girl leaves the classroom crying, and his values permeate his meaning-oriented reflections (Hoekstra \& Korthagen, 2011). Peter can also 
act intuitively, but admits that he has a deep-seated understanding of the way he should respond. He has obviously previously reflected on how he can tackle a student fight. He just does what he has to do, and delays both his reflection on it and his dialogue with the pupils. He acts mindfully (Kabat-Zinn, 1984, 1990, 2003) and is highly aware of the present moment and what is happening, but also delays making any judgements (Poulson et al., 2013). He thinks that his role as a teacher has influenced him as a person and how he performs his school practice. He is confident and aware of what is important for him as a person and a teacher. According to Hamachek (1999), the more awareness of yourself the more your personal decisions will contribute to better teaching. It is obvious that Peter as a person is present in his role as a teacher, and that the person and profession are intertwined. It is the "personalized nature of teaching" (Day, 1999: p. 94) that he is practising.

For Jane, it is important that the pupils feel happy, and the pupils' happiness also makes her satisfied. Jane, like Peter, has her pupils and their learning and well-being in focus when she talks about situations in her practice, and her reflections are therefore meaning-oriented (Hoekstra \& Korthagen, 2011). But her stories from practice show that it can be difficult to live up to this aim in all situations in school. Her intention with an activity after a test in mathematics was that the pupils should learn from their mistakes. But the pupils did not live up to her intentions. She blames herself for not organising the activity well enough. According to Osher, Bear, Sprague and Doyle (2010), classroom management can be built into different activities that create and maintain order in the classroom, but she has not managed to put her leadership into the activity. Jane reflects on her own response to the pupils and that it was like punishing all of them, also the pupils who worked well, for the "crimes" of some. She is not content with her own response, and says that her log writing, a task assigned as part of this study, made her reflect on how to organise and execute this activity differently the next time. Thus, reflection on practice and the consequences of the accomplished actions can lead to learning and development of practice (Dewey, 1916). Jane also realises that she should have thought about and planned topics that could have been relevant for the class circle beforehand, and thinks that if she had been better prepared she could have managed to turn the discussion towards other themes than just spinning negatively around the same topic. It is obvious that her reflections on the performed actions and their consequences developed her understanding of the experienced situation and thus also probably her planning and acting during new similar situations. Then her teaching would not be mechanical and repressive (Durkheim, 1956), but guided by her core values (Hoekstra \& Korthagen, 2011).

When it comes to the parent-teacher conference, Jane blames herself for not checking the agreement between the parents before the conference. In this situation she also places the pupil in the centre and wants her to feel safe at school. That is her conviction and her aim. When Jane talks about the substitute teacher situation, where she has to step in with ten minutes to spare before she meets the class, she also places the pupils at the centre, and does her best to develop a good plan for the lesson during the few minutes she has at her disposal. Jane wants all the best for her students, but she can also react automatically, not delaying her judgement (Poulsen, et al., 2013). When she understands that she has acted before having all the facts, she apologises to the pupil in question. In this way she can maintain a good relationship with the pupils in the class. This was a personal decision based on her values that contributed to a correction of and improvement in her teaching (Hamachek, 1999).

Kari also bases her actions and reflections on beliefs and values. When she holds back from talking to the assistant who is making a disturbance in her classroom, it is because she does not want others at school to pass on attitudes she does not identify with. In her meaning-oriented reflections (Hoekstra \& Korthagen, 2011), she does not want there to be any distance between people, even if there is one in terms of education background. She also shows special care for pupils from other countries than Norway, and thinks that the mother-tongue teachers have too high expectations for the pupils. Kari defends the pupils and argues against the belief that they are not putting enough effort into their work, saying instead that they do not understand what to do. It is obvious that Kari takes care of the pupils in her class, and especially the pupil from Poland, whom she talked about as a challenge. At the same time, she contemplates how this pupil could become more independent. Kari obviously has the same respect for people, whether they are well educated or not or come from another country. She wants everyone to be included in a community of acceptance, and she joins pupils from other countries when buying sportswear to make it even easier for them to become part of the community of their peers. She also goes with them to football matches to watch them play. Her values are manifested in her actions. Kariis fully aware of what she believes, but struggles to see all her pupils during the lessons, even though she knows the importance of seeing the pupils from theory she has read during further education studies.

The teachers think that experiences gained from practice help them to develop further as teachers. They are 
apprentices of practice (Postholm \& Rokkones, 2015), but it seems to be difficult to describe how they have changed their practice. They do not feel that their basic teacher education is present during their work in school, but they all think that theory in some way serves as an anchor for their understanding. Jane and Kari say that the further education they have taken while working in school at the same time has been a help because they then can link it directly to and use it in their practice. Kari says that she could have learned from the basic teacher education now after having been in practice because now she has experience that she can connect the theory to. All three refer to their colleagues as the best help for dealing with practice and learning from practice. Research shows that teachers learn from interaction in communities of professionals (Fishman \& Davis, 2006; Grossman et al., 2001; Meirink et al., 2009), but they all feel too little time is devoted to collective work in school. As they have a deep understanding of the advantage of collaboration, they meet on their own initiative once a week.

When the teachers come together in a joint dialogue they talk about how they strive to adapt the teaching to the pupils so they all have a feeling of mastering. They see the importance of being present in practice and thus having good relations with the pupils, which Marzano (2009) maintains is a cornerstone of classroom management. They are dedicated to seeing the pupils and helping them to learn and experience well-being in school. The teachers also regard collaboration with their colleagues as the most important source of their learning in school. Teacher's professional development means teachers' learning, how they learn to learn and how they apply their knowledge in practice to support pupil learning (Avalos, 2011). The teachers in this study say that they learn from their experiences, they can reflect on them together with their colleagues and thus they have a metacognitive overview (Boekaerts, Pintrich, \& Zeidner 2000; Flavell, 1976; Zimmerman, 2006) of their own experiences and can therefore learn to learn. Furthermore, they claim that their learning is directed at how they can see the pupils and support them in their learning. In this way their practice in school can contribute to their continuous professional learning.

\section{Concluding Reflections}

The point of departure for this article was how experienced teachers respond to and reflect on challenging situations in school. The study shows that the three experienced teachers react to situations in different ways. It seems that Peter is calm in situations that challenge him, and he delays his judgements. He also takes the time to reflect with his colleagues. There seems to be a culture for learning in the teacher team, but they do not have a structure for collaboration work at the school that focuses on teachers learning in their practice. Collective collaborative learning is a positive form of continuing the professional development of teachers, but both structure and culture can lay the foundation for and ought to be in interplay with each other to foster professional development (Forte \& Flores, 2014). In the same way that the timetable includes meeting points between teachers and pupils, it should also include meeting points for teachers to focus on their learning. If teachers are to develop their practice, they also need new knowledge to make them think of their practice in new ways. Darling-Hammond and Richardson (2009) propose reading literature in study groups as an activity for teachers' learning. From this study it seems likely that the teachers also need someone to lead them in their learning. If teachers' learning is to be emphasised in school, then leaders who have knowledge about and are willing to focus on their learning are needed. The leaders can invite external experts to school or suggest texts the teachers can read as a thinking tool for development (Gudmundsdottir, 2001), and they can arrange for and support a learning culture at school. Teachers also need methodological competence so they can be analytical in their own practice. According to Timperley, Wilson, Barrar \& Fung (2007), the analysis and use of data collected from the classroom is an essential part of the teachers' professional development. This data can be the pupils' thoughts expressed during interviews, observation of the pupils working in the classroom and results from tests. One of the teachers in the study states that writing a log for fourteen days helped her to reflect on her teaching. If teachers continuously were systematic in their practice, using data to reflect both individually and collectively, they would have every opportunity to really make their practice an art of the teacher.

The teachers in this study found it difficult to relate their teacher education to real practice. The described situations and the experienced teachers' reflections on them might help pre-service teachers to link their learning on campus to real situations in school if used in teacher education. The text can also be used as a thinking tool for both novice teachers and in-service teachers as they learn to cope with various situations in practice and to understand the importance of reflection in their own practice in school. The teacher as a person also seems to permeate their role as teachers. Research focusing on newly qualified teachers shows that teachers' personal and 
professional histories influence who they become as teachers (Flores \& Day, 2006). Future studies are also needed to help us to understand the biography of experienced teachers and what their background means for them in their professional role as teachers. The study which this article is based on has researched just three teachers. Future research could include more research participants to get a broader picture of how experienced teachers reflect on challenging situations in school.

\section{References}

Argyris, C., \& Schön, D. A. (1978). Organizational Learning: A Theory of Action Perspective. Reading. Mass.: Addison-Wesley.

Avalos, B. (2011). Teacher Professional Development in Teaching and Teacher Education over Ten Years. Teaching and Teacher Education, 27, 10-20. http://dx.doi.org/10.1016/j.tate.2010.08.007

Boekaerts, M., Pintrich, P., \& Zeidner, M. (2000). Self-Regulation: An Introductory Review. In M. Boekarts, P. R. Pintrich, \& M. Zeidner (Eds.), Handbook of Self-Regulation (pp. 1-9). San Diego, CA: Academic Press. http://dx.doi.org/10.1016/B978-012109890-2/50030-5

Camburn, E. M. (2010). Embedded Teacher Learning Opportunities as a Site for Reflective Practice: An Exploratory Study. American Journal of Education, 16, 463-489. http://dx.doi.org/10.1086/653624

Darling-Hammond, L., \& Richardson, N. (2009). Teacher Learning: What Matters? Educational Leadership, 66, 46-53.

Day, C. (1999). Developing Teachers: The Challenges of Lifelong Learning. London: Falmer.

Desimone, L. M. (2009). Improving Impact Studies of Teachers’ Professional Development: Toward Better Conceptualizations and Measures. Educational Researcher, 38, 181-199. http://dx.doi.org/10.3102/0013189X08331140

Dewey, J. (1916). Democracy and Education. An Introduction to the Philosophy of Education. New York: Macmillan Company.

Doyle, W. (2006). Ecological Management to Classroom Management. In C .M. Evertson, \& C. S. Weinstein (Eds.), Handbook of Classroom Management: Research, Practice, and Competence Issues (pp. 97-125). Mahwah: Lawrence Erlbaum Associated.

Dunst, C. J., Johanson, C., Rounds, T., Trivette, C. M., \& Hamby, D. (1992). Characteristics of Parents-Professional Partnerships. In S. L. Christenson, \& J. C. Conoley (Eds.), Home-School Collaboration: Enhancing Children's Academic and Social Competence. Silver Spring, MD: National Association of School Psychologists.

Durkheim, E. (1956). “The Nature and Method of Pedagogy" and "The Evolution and the Role of Secondary Education in France” in Education and Sociology. New York: The Free Press.

Fishman, B. J., \& Davis, E. A. (2006). Teachers Learning Research and the Learning Sciences. In R. K. Sawyer (Ed.), The Cambridge Handbook of the Learning Sciences (pp. 535-559). Cambridge: Cambridge University Press.

Flavell, J. H. (1976). Metacognitive Aspects of Problem Solving. In L. B. Resnick (Ed.), The Nature of Intelligence (pp. 231-235). Hillsdale, NJ: Earlbaum.

Flores, M. A., \& Day, C. (2006). Contexts Which Shape and Reshape New Teachers' Identities: A Multi-Perspective study. Teaching and Teacher Education, 22, 219-232. http://dx.doi.org/10.1016/j.tate.2005.09.002

Fontana, A., \& Frey, J. H. (1998). Interviewing: The Art of Science. In N. K. Denzin, \& Y. S. Lincoln (Eds.), Collecting and Interpreting Qualitative Materials (pp. 47-78). Thousand Oaks: Sage Publications, Inc.

Forte, A. M., \& Flores, M. A. (2014). Teacher Collaboration and Professional Development in the Workplace: A Study of Portuguese Teachers. European Journal of Teacher Education, 37, 91-105.

http://dx.doi.org/10.1080/02619768.2013.763791

Garfinkel, H. (1967). Studies in Ethnomethodology. Englewood Cliffs, NJ: Prentice Hall.

Geertz, C. (1973). The Interpretation of Cultures. New York: Basic Books.

Grossman, P., Wineburg, S., \& Woolwort, S. (2001). Toward a Theory of Teacher Community. Teachers College Record, 103, 942-1012. http://dx.doi.org/10.1111/0161-4681.00140

Gudmundsdottir, S. (2001). Narrative Research in School Practice. In V. Richardson (Ed.), Fourth Handbook for Research on Teaching (pp. 226-240). New York: Macmillan.

Hargreaves, A. (1998). The Emotions of Teaching and Educational Change. In A. Hargreaves, A. Lieberman, M. Fullan, \& D. Hopkins (Eds.), International Handbook of Educational Change (pp. 558-575). Dordrecht: Kluwer. http://dx.doi.org/10.1007/978-94-011-4944-0_28

Hoekstra, A., \& Korthagen, F. (2011). Teacher Learning in a Context of Educational Change: Informal Learning versus Systematically Supported Learning. Journal of Teacher Education, 62, 76-92. 
http://dx.doi.org/10.1177/0022487110382917

Jennings, P. A., \& Greenberg, M. T. (2009). The Prosocial Classroom: Teacher Social and Emotional Competence in Relation to Student and Classroom Outcomes. Review of Educational Research, 79, 491-525. http://dx.doi.org/10.3102/0034654308325693

Kabat-Zinn, J. (1984). An Outpatient Program in Behavioral Medicine for Chronic Pain Patients Based on the Practice of Mindfulness Meditation: Theoretical Considerations and Preliminary Results. General Hospital Psychiatry, 4, 33-47. http://dx.doi.org/10.1016/0163-8343(82)90026-3

Kabat-Zinn, J. (1990). Full Catastrophe Living. Using the Wisdom of Your Body and Mind to Face Stress, Pain and Illness. New York: Bantam Doubleday Dell Publishing.

Kabat-Zinn, J. (2003). Mindfulness-Based Interventions in Context: Past, Present, and Future. Clinical Psychology: Science and Practice, 10, 144-156. http://dx.doi.org/10.1093/clipsy.bpg016

Korthagen, F. A. J. (2004). In Search of the Essence of a Good Teacher: Towards a More Holistic Approach in Teacher Education. Teaching and Teacher Education, 20, 77-97. http://dx.doi.org/10.1016/j.tate.2003.10.002

Kvale, S., \& Brinkmann, S. (2009). Det kvalitative forskning intervju [The Qualitative Research Interview]. Oslo: Gyldendal Akademisk.

Lewis, R., Romi, S., Katz, Y. J., \& Qui, X. (2008). Students’ Reaction to Classroom Discipline in Australia, Israel, and China. Teaching and Teacher Education, 24, 715-724. http://dx.doi.org/10.1016/j.tate.2007.05.003

Lincoln, Y. S., \& Guba, E. G. (1985). Naturalistic Inquiry. Beverly Hills, CA: Sage Publications, Inc.

Lortie, D. C. (1975). Schoolteacher: A Sociological Study. Chicago, IL: University of Chicago Press.

MacDonald, E., \& Shirley, D. (2009). The Mindful Teacher. New York: Teachers College Press.

Marzano, R. J. (2009). Classroom Management that Works-Research Based Strategies for Every Teacher. New York: Pearson Education Inc.

Marzano, R. J., Marzano, J. S., \& Pickering, D. J. (2003). Classroom Management That Works. Research-Based Strategies for Every Teacher. New York: Pearson Education.

Meirink, J. A., Meijer, P. C., \& Verloop, N. (2009). How Do Teachers Learn in the Workplace? An Examination of Teacher Learning Activities. European Journal of Teacher Education, 32, 209-224. http://dx.doi.org/10.1080/02619760802624096

NESH (2006). Forskningsetiske retningslinjer for samfunnsvitenskap, jus og humaniora [Research Ethical Guidelines for Social Science, Law and the Humanities]. Oslo: Norwegian National Committees for Research Ethics. http://www.etikkom.no/no/Vart-arbeid/Hvem-er-vi/Komite-for-samfunnsvitenskap-og-humaniora/

Osher, D., Bear, G. G., Sprague, J. R., \& Doyle, W. (2010). How Can We Improve School Discipline? Educational Researcher, 39, 48-58. http://dx.doi.org/10.3102/0013189X09357618

Palmer, P. J. (2003). Teaching with the Heart and Soul-Reflections on Spirituality in Teacher Education. Journal of Teacher Education, 54, 376-385. http://dx.doi.org/10.1177/0022487103257359

Paulson, S., Davidson, R., Jha, A., \& Kabat-Zinn, J. (2013). Becoming Conscious: The Science of Mindfulness. Annals of the New York Academy of Science, 1303, 87-104. http://dx.doi.org/10.1111/nyas.12203

Postholm, M. B. (2010). Kvalitativ metode. En innføring med fokus på fenomenologi, etnografi og kasusstudier. [Qualitative Method. An Introduction Focusing on Phenomenology, Ethnography and Case Studies] (2nd ed.). Oslo: Universitetsforlaget/University [Publishing Firm].

Postholm, M. B. (2012). Teachers' Professional Development: A Theoretical Review: Educational Research, 54, 405-429. http://dx.doi.org/10.1080/00131881.2012.734725

Postholm, M. B., \& Rokkones, K. (2013). Videreutdanning i yrkesfaglige programfag: Læreres opplevelser av studiets betydning for egen læring og yrkesutøvelsen i skolen [Further Education in Vocational Subjects. Teachers' Experiences of the Studies' Importance for Their Own Learning and Their Practice of the Profession in School]. Tidsskriftet Fo Uipraksis [The Journal: R\&D in Practice], 7, 93-111.

Postholm, M. B., \& Rokkones, K. (2015). Teachers’ and School Leaders’ Perceptions of Further Education and Learning in School. Creative Education, 6, 2447-2458. http://dx.doi.org/10.4236/ce.2015.623252

Richter, D., Kunter, M., Klausmann, U., Lüdtke, O., \& Baumert, J. (2011). Professional Development across the Teaching Career: Teachers' Uptake of Formal and Informal Learning Opportunities. Teaching and Teacher Education, 27, 116-126. http://dx.doi.org/10.1016/j.tate.2010.07.008

Sacks, H. (1992). Lectures on Conversation. Oxford: Blackwell.

Shulman, L. S. (1986). Those Who Understand: A Conception of Teacher Knowledge. American Educator, 10, 9-15.

Strauss, A., \& Corbin, J. (1998). Basics of Qualitative Research: Techniques and Procedures for Developing Grounded 
Theory. Thousand Oaks, CA: Sage Publications, Inc.

Timperley, H., Wilson, A., Barrar, H., \& Fung, I. (2007). Teacher Professional Learning and Development: Best Evidence Synthesis Iteration. Wellington: Ministry of Education. https://www.educationcounts.govt.nz/publications/series/2515/15341

Zimmerman, B. J. (2006). Development and Adaption of Expertise: The Role of Self-Regulatory Processes and Beliefs. In K. A. Ericsson, N. Charness, P. J. Feltovich, \& R. R. Hoffman (Eds.), The Cambridge Handbook of Expertise and Expert Performance (pp. 705-722). Cambridge: Cambridge University Press. http://dx.doi.org/10.1017/CBO9780511816796.039

\section{Submit or recommend next manuscript to SCIRP and we will provide best service for you:}

Accepting pre-submission inquiries through Email, Facebook, Linkedin, Twitter, etc A wide selection of journals (inclusive of 9 subjects, more than 200 journals)

Providing a 24-hour high-quality service

User-friendly online submission system

Fair and swift peer-review system

Efficient typesetting and proofreading procedure

Display of the result of downloads and visits, as well as the number of cited articles

Maximum dissemination of your research work

Submit your manuscript at: http://papersubmission.scirp.org/ 